\title{
GRANULATION RED INDEX TO ASSESS PRESSURE ULCER GRANULATION TISSUE QUALITY TREATED BY HONEY GAUZE DRESSING BY DIGITAL IMAGE ANALYSIS
}

\author{
Fory Fortuna ${ }^{1}$, Nandita Melati Putri ${ }^{2 *}$, Gentur Sudjatmiko² \\ Department of Surgery, Universitas Andalas, RSUD M Jamil, Padang, Indonesia \\ 2. Wound and Oncoplasty Section, Division of Plastic Surgery, Department of Surgery, Universitas Indonesia, dr. Cipto Mangunkusumo \\ Hospital, Jakarta, Indonesia
}

Introduction: Good formation of granulation tissue in the ulcer bed is regarded as one of the indicators of pressure ulcer healing. Granulation red index (GRI) had been published as an objective parameter to assess the quality of granulation tissue. Honey stimulates granulation of tissue and creates a moist healing environment. However, the assessment of granulation tissue quality of pressure ulcers treated by honey has yet to be proven in clinical settings. In this study, we evaluate the granulation tissue quality of pressure ulcers treated by honey using granulation red index by digital image analyses.

Methods: There were 12 subjects who fulfill inclusion criteria treated by honey gauze dressing and were evaluated every week for three times measurements of \%GRI and DESIGN--score. Parameters of this study were the delta \%GRI80 and DESIGN--R score. Correlations were evaluated by Spearman's correlation coefficient.

Results : The correlation of delta GRI $80 \%$ and DESIGN--R score was statistically significant from baseline measurement to first week of treatment and to second week of treatment $(\mathrm{r} 1=0.65, \mathrm{p} 1=0.02$ and $\mathrm{r} 3=0.832, \mathrm{p} 2=0.001)$. The correlation of delta GRI $80 \%$ and DESIGN--R score from first to second week therapy was not statistically significant $(r=0.23, p=0.47)$, but the GRI $80 \%$ from first week therapy to second week of therapy was increasing and DESIGN R score was decreasing.

Conclusion:This study shows the correlation of \%GRI80 and DESIGN--R score of pressure ulcer after the treatment of honey gauze dressing. This study hopefully assists further study for wound bed preparation assessment and treatment of pressure ulcer for surgical intervention.

Keywords: Granulation; honey; GRI; \% GRI80; digital image analyses; DESIGN--R tool

Latar Belakang: Pembentukan jaringan granulasi yang baik di dasar ulkus dianggap sebagai salah satu indikator penyembuhan ulkus tekan. Granulasi Red Index (GRI) telah dipublikasikan sebagai parameter objektif untuk menilai kualitas jaringan granulasi. Madu merangsang granulasi jaringan dan menciptakan lingkungan penyembuhan yang lembab. Namun, penilaian kualitas jaringan granulasi ulkus tekan yang diobati dengan madu belum terbukti dalam pengaturan klinis. Dalam penelitian ini, kami mengevaluasi kualitas jaringan granulasi ulkus tekan yang diobati dengan madu menggunakan Granulasi Red Index (GRI) dengan analisis digital.

Metode: Terdapat 12 subjek yang memenuhi kriteria inklusi yang dirawat dengan pembalutan kasa madu dan dievaluasi setiap minggu untuk tiga kali pengukuran \% GRI dan skor DESIGN-R. Parameter dari penelitian ini adalah delta \% GRI80 dan skor DESIGN-R. Korelasi dievaluasi oleh koefisien korelasi Spearman.

Hasil: Korelasi skor delta GRI80\% dan DESIGN-R terdapat nilai yang signifikan secara statistik dari pengukuran awal untuk minggu pertama pengobatan hingga minggu kedua pengobatan $(\mathrm{r} 1=0,65$, $\mathrm{p} 1=0,02$ dan $\mathrm{r} 3=0,832, \mathrm{p} 2=0,001)$. Korelasi skor delta GRI80\% dan DESIGN-R dari terapi minggu pertama ke kedua tidak signifikan secara statistik ( $\mathrm{r}=$ $0,23, p=0,47)$, tetapi GRI $80 \%$ dari terapi minggu pertama ke minggu kedua terapi meningkat dan DESAIN R skor menurun.

Kesimpulan: Penelitian ini menunjukkan korelasi\% GRI80 dan skor DESIGN -- $\mathrm{R}$ ulkus setelah perawatan menggunakan kasa madu. Studi ini diharapkan membantu studi lebih lanjut untuk penilaian luka dan perawatan ulkus tekan pada intervensi bedah.

Kata Kunci: Granulasi; Madu; GRI; \% GRI80; Analisis Gambar Digital; DESIGN--R

\section{Conflicts of Interest Statement:}

The author(s) listed in this manuscript declare the absence to any conflict of interest on the subject matter or materials discussed. 


\section{INTRODUCTION}

Pressure ulcers impair patient quality of life (QOL), increase medical costs, and place a high burden on the healthcare system. ${ }^{1,2,8}$ The management of pressure ulcers is interdisciplinary. ${ }^{1}$ The basic principles of pressure ulcer management are reducing or relieving pressure on the skin, debriding necrotic tissue, managing bacterial load and colonization, cleansing the wound and selecting a wound dressing. There has been some research and development in the area of dressings. The use of hydrocolloid, transparent film, hydrogel, alginate, foam, polymeric membrane, silver--impregnated, honey--impregnated, cadexomer iodine-impregnated, gauze, silicone--coated, collagen matrix, and composite dressings for the treatment of pressure ulcers are recommended for the last decades. $^{2}$

Honey gauze for wound dressing had been used since 2010 in our hospital (Ayu Diah, 2010, Sundoro Ali, 2010). Honey stimulates granulation of tissue and creates a moist healing environment. The formation of granulation tissue is an essential process in full--thickness (grade III--IV) pressure ulcer healing. 3,4,5 However, the assessment of granulation tissue quality of pressure ulcers treated by honey has yet been proven in clinical settings. Granulation red index (GRI) with $\%$ GRI80 had been published as an objective parameter to assess the quality of granulation tissue (lizaka et al, 2011). DESIGN--R (rating) is a clinical wound assessment tool by the Scientific Education Committee of the Japanese Society of Pressure Ulcers and it is widely used in Japan and in Asian countries since 2010.7

In this study, we evaluate the granulation tissue quality of pressure ulcers treated by honey using granulation red index by digital image analysis and investigate its correlation with DESIGN--R score. Problem in this study is to find if there is any correlation of \%GRI80 of pressure ulcer granulation tissue progression with its DESIGN-- $\mathrm{R}$ score progression after treatment of honey gauze dressing.

Aim of this study is to discover appropriate tool to assess the granulation tissue quality of full thickness pressure ulcer quantitatively.

\section{METHOD}

This research is a preliminary prospective study to evaluate the correlation of \%GRI80 of pressure ulcer granulation tissue with DESIGN--R score progression of each pressure ulcer after treatment of honey gauze dressing. Population are adult patient which in condition pressure ulcer on hospitalized in Plastic Surgery Division dr. Ciptomangunkusumo Hospital within December 2014 to January 2015 who meet inclusion criteria. The inclusion criteria are full thickness pressure ulcer on adult patients treated by honey gauze dressing. The exclusion criteria are hemoglobin level is lower than $8 \mathrm{gr} / \mathrm{dl}$, malnutrition, bleeding pressure ulcer, partial thickness pressure ulcer, other ulcers (diabetic ulcer, carcinomatous ulcer), pressure ulcer that is still covered by eschar or necrotic tissue, and pressure ulcer that is already treated by other dressing modalities.

Patients with pressure ulcer those are hospitalized in dr. Ciptomangunkusumo Hospital and treated by honey gauze dressing within Desember 2014 - January 2015 were selected based on inclusion and exclusion criteria. Patient demographics including age, sex and comorbidities were collected. ${ }^{13}$ Honey gauze is made by mixing the gauze with honey (Madu Nusantara ${ }^{\mathrm{TM}}$ ) that we usually used based on the previous study. $15,16,17$

Each pressure ulcer (PU) was become a subject and were assessed by DESIGN--R score tool before therapy and every week for 2 weeks. The total score (range 0-66) was calculated from six parameters, excluding depth, based on the healing time, and the score of $>18$ indicates severe PUs mostly taking more than 3 months to heal. ${ }^{14}$ The predictive validity and interrater reliability of the DESIGN--R tool have been confirmed by Sanada H, et al 2011. 8,15

The wound was captured by digital point--and--shoot camera (Lumix DMC-- TZ40, Panasonic Co., Japan). During the procedure, patients lay down on their bed in lateral position. A commercially available reference color chart with nine calibrated colors (Casmatch, BEAR Medic Co., Ibaraki. Japan) was vlaced at the surrounding skin 
Automated white balance, and automated International Organization for Standardization (ISO) sensitivity. A flash was used except in an extreme underexposure environment. The distance between a wound and a camera was approximately $30 \mathrm{~cm}$, but slightly changed according to wound size. The photographs were stored in the JPEG format. 9,13

Acquired photographs were processed by digital image analysis using two processes: color calibration and image calculation. The color calibration can standardize the brightness and contrast of photographs taken under different conditions. Color calibration will be conducted according to the standard protocol of the color chart by image--editing software (Photoshop 6; Adobe Systems Inc., San Jose, CA, USA). The dropper tool will be used to set the level of three standard color markers, including highlight, shadow and gamma. 9,13

Image calculation for the GRI, which reflected the degree of redness, was performed using ImageJ soft--ware (National Institutes of Health, Bethesda, MD, USA). After the red (R) and green (G) channels of the digital color images were transformed logarithmically, the images obtained from $(\log R-\log G)$ by the image calculator tool (Figure 1C and 1D).

Subsequently, another calibration was applied to the image, in which the intensity of the whole image was multiplied by a factor given by $150 /$ (the mean intensity of the red color marker).
Through this process, the intensity of the red color marker was further standardized and the intensity of any region in a GRI image was expressed as a relative value. ${ }^{9,13}$

To calculate the color indicators, a researcher manually selected the region of granulation tissue using a freehand tool. The areas of non--granulation tissue, defined as areas with localized slough, necrotic tissue, bleeding and exposed subcutaneous fat, fascia, or bone, were excluded. In the region of interest-i.e. the granulation tissue area-the \%GRI80 will be calculated, which represents the proportion of pixels exceeding the threshold intensity of 80 for the total number of pixels on the granulation tissue surface (Figure 1C and 1D). The reliability, concurrent validity and predictive validity of $\%$ GRI80 and its cutoff points were reported in previous studies; inter--rater reliability for calculation of GRI value in the same photograph was almost optimal from previous study by Lizaka, et al 2011.

Each sample was evaluated every week for three times measurement by capturing the pressure ulcer site and DESIGN--R score calculation. In this research, data were processed using SPSS version 22.0. Correlations were evaluated by Spearman's correlation coefficient for not normally distributed data.
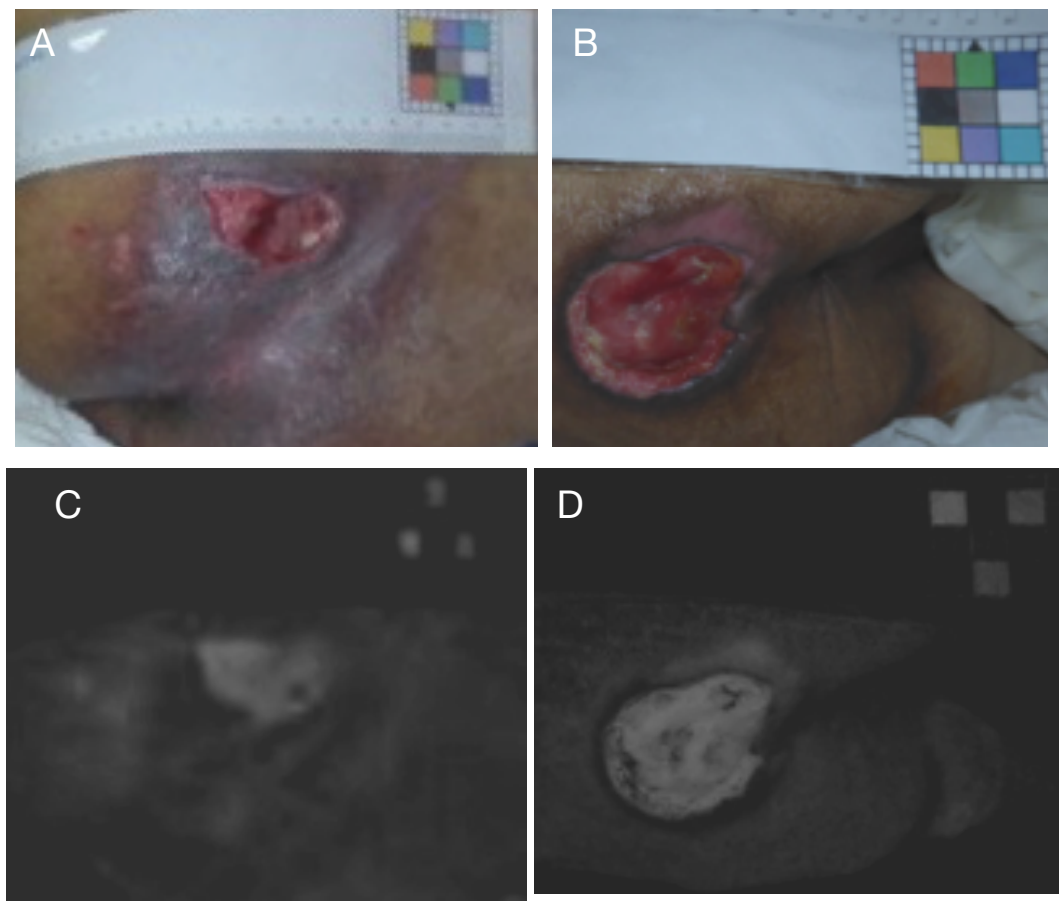

Figures 1. Representative cases of granulation red index (GRI) (A, B): Pressure ulcers with clinically poor and good granulation tissue. (C,D): Images representing the GRI for each wound. The \%GRI80 was the proportion of pixels exceeding the threshold intensity of 80 on the granulation tissue. The \%GRI80 levels were 63,65.3\% (C) and 99.2\%

(D).surface and it resembles the "harlequin" given the figure on extreme right 


\section{RESULT}

All together, 11 patients with 12 full thickness PUs met the inclusion criteria and participated in this study. They are pressure ulcers on 7 female patients and 4 male patients. Mean of age was 40,5 . Standard deviation was 22.74 (Table 1). Table 2 describes the he progression correlation of \%GRI80 and DESIGN--R score was significant from baseline measurement to first week of treatment and to second week of treatment $(\mathrm{r} 1=0.65, \mathrm{p} 1=0.02$ and $\mathrm{r} 3=0.832, \mathrm{p} 2=0.001)$. The progression correlation of GRI80\% and DESIGN-$\mathrm{R}$ score from first to second week therapy was not statistically significant $(\mathrm{r}=0.23, \mathrm{p}=0.47)$, but the $\%$ GRI80 and DESIGN--R Score from first week therapy to second week of therapy was increasing (Table 3).

Table 1. Demographic data

\begin{tabular}{lccccc}
\hline Categories & N & Minimum & Maximum & Mean & Std. Deviation \\
\hline Umur & 11 & 7.00 & 67.00 & 40.545455 & 22.741087 \\
Valid (listwise) & N 11 & & & & \\
\hline
\end{tabular}

\section{Descriptive Statistics}

Table 2. Progression Correlation (delta) of DESIGN--R Score and \%GRI80

\begin{tabular}{lccc}
\hline No & \multicolumn{1}{c}{\begin{tabular}{c} 
P-value \\
\hline 1.
\end{tabular}$\quad$ Delta for baseline to first week } \\
of treatment & 0.65 & 0.02 \\
2. & $\begin{array}{c}\text { Delta for first week to second week of } \\
\text { treatment }\end{array}$ & 0.23 & 0.47 \\
3. & $\begin{array}{c}\text { Delta for baseline to second week } \\
\text { of treatment }\end{array}$ & 832 & 1 \\
\hline
\end{tabular}

Table 3. \%GRI80 and DESIGN R Score Measurements

\begin{tabular}{|c|c|c|c|c|c|c|}
\hline Subject & \%GRI80 I & \%GRI80 II & \%GRI80 III & $\begin{array}{c}\text { Score } \\
\text { I }\end{array}$ & $\begin{array}{l}\text { Score } \\
\text { II }\end{array}$ & $\begin{array}{c}\text { Score } \\
\text { III }\end{array}$ \\
\hline 1 & 95,98 & 97.63 & 100 & 20 & 15 & 14 \\
\hline 2 & 93,69 & 95,21 & 99,91 & 19 & 15 & 11 \\
\hline 3 & 93.97 & 94,1 & 94.91 & 15 & 13 & 11 \\
\hline 4 & 69,7 & 74,5 & 81,24 & 16 & 11 & 8 \\
\hline 5 & 76.22 & 79.2 & 96.7 & 16 & 16 & 6 \\
\hline 6 & 43.55 & 76,84 & 99.2 & 30 & 15 & 14 \\
\hline 7 & 91.3 & 94,44 & 96,26 & 18 & 14 & 11 \\
\hline 8 & 72.73 & 92.79 & 95.69 & 19 & 13 & 11 \\
\hline 9 & 87,88 & 98,17 & 98.22 & 20 & 17 & 14 \\
\hline 10 & 45,81 & 91,5 & 97,09 & 18 & 10 & 8 \\
\hline 11 & 68,49 & 79,84 & 91,88 & 19 & 15 & 11 \\
\hline 12 & 63,65 & 67,72 & 69,76 & 13 & 11 & 10 \\
\hline
\end{tabular}




\section{DISCUSSION}

Preoperative preparation is cautious consideration in the management of pressure ulcer. Medical grade honey is one of the recommended dressing for pressure ulcer treatment. ${ }^{2}$ The assessment of granulation tissue quality of pressure ulcer is important to determine the management especially for surgical intervention. Recommendations focus on early identification of patients at high risk for pressure ulcer infection and early recognition of critical colonization and local infection using more subtle clinical indicators, such as new or increasing ulcer pain, pocketing, friable granulation tissue, and increased drainage.,2,17

To evaluate the treatment of honey gauze dressing, this study used Granulation Red Index by digital image analysis using the Image J application. This GRI was first described by lizaka, et al in 2010. The concurrent validation and reliability was already studied with the result that GRI from digital image analysis can quantitively evaluate granulation tissue color of clinical PUs. To see the clinical correlation, we used DESIGN--R tool of each pressure ulcer. Increasing GRI80\% and decreasing of DESIGN--R score means good progression of pressure ulcer healing. $7,8,9$

First week of treatment progression was the delta score before and after honey gauze treatment. Second week of treatment progression was the delta score after first week of treatment to second week of treatment. Two weeks of treatment progression was the delta score of baseline measurement to after two weeks of treatment measurements.

Strong correlation between the progression of GRI80\% and DESIGN--R Score was obtained on delta for baseline to second week of treatment $(\mathrm{r}=0.832$, $\mathrm{p}=0.001)$. Correlation was also statistically significant on delta for baseline to first week of treatment $(r=0.65$, $p=0.02$ ). More study with more subjects is needed to prove the progression correlation for the progression after first week of honey gauze treatment on full thickness pressure ulcer.

The limitation of subjects is the will to accept surgical procedure for wound closure. So, we couldn't assess the granulation tissue quality and correlate it to the success of surgical procedure. In order to obtain better result of pressure ulcer management, especially for surgical intervention, further study is needed to see the correlation of \%GRI 80 before surgery with the success rate of surgical procedure and also its correlation with factors that can affect the wound bed preparation such as: kind of bacteria exist and bacterial load on wound bed also the enzymes which influence wound healing especially for chronic wound.
The limitation of this study is that this research only correlate the progression of \%GRI80 and the progression of it's DESIGN--R score after treatment of honey gauze dressing. Further study is needed to correlate the progression of GRI and score to prepare the wound closure to determine the \%GRI80 cut off point of a good pressure ulcer wound bed for closure.

\section{CONCLUSION}

The result of this study shows the correlation of \%GRI80 of granulation tissue and DESIGN $\mathrm{R}$ score of pressure ulcer after the treatment of honey gauze dressing. GRI80\% scores of pressure ulcer granulation tissue were increasing and the scores of DESIGN--R were decreasing every week in every subject as the sign of good progression of pressure ulcer healing.

This preliminary study of \%GRI80 of pressure ulcer granulation tissue after honey gauze treatment, hopefully support quantitative and objective wound assessment in order to obtain good result of pressure ulcer management for conservative treatment. This study also hopefully assists further study for wound bed preparation assessment and treatment of pressure ulcer for surgical intervention.

\section{Correspondence regarding this article should be addressed to:}

Nandita Melati Putri, M.D

Wound and Oncoplasty Section, Division of Plastic Surgery, Department of Surgery, Universitas Indonesia, dr. Cipto Mangunkusumo Hospital, Jakarta, Indonesia

E-mail:nalatri@yahoo.com 


\section{REFERENCES}

1. Bluestein D, Javaheri A. Pressure Ulcer: Prevention, Evaluation, and Management. J Am Fam Phys. 2008;78(10): 1186--1194.

2. Black J, McNichol L, Zulkowski K, et al. National Pressure Ulcer Advisory Panel and European Pressure Ulcer Advisory Panel. Pressure Ulcer Treatment: Technical Report. Washington DC: National Pressure Ulcer Advisory Panel; 2009. Available at www.npuap.org.

3. Bergstrom N, Horn SD, Smout R J, et al. The National Pressure Ulcer Long--Term Care Study: Outcomes of Pressure Ulcer Treatments in Long-Term Care. J Am Geriatr Soc. 2005;53: 1721-- 1729.

4. Broughton G 2nd, Janis JE, Attinger CE. The basic science of wound healing. Plast Reconstr Surg 2006; 117 (Suppl. 7): 12S-34S.

5. Baum CL, Arpey CJ. Normal cutaneous wound healing: clinical correlation with cellular and molecular events. Dermatol Surg 2005; 31: 674-86.

6. Iizaka S, Sanada H, Minematsu T, Oba M, Nakagami G, Koyanagi H, Nagase T, Konya C, Sugama J. Do nutritional markers in wound fluid reflect pressure ulcer status? Wound Rep Regen. 2010; 18: 31-7.

7. Matsui,Y., Furue, M., Sanada, H, et al. Development of the DESIGN--R with an observational study: An absolute evaluation tool for monitoring pressure ulcer wound healing. Wound Rep Regen. 2011 (19): 309-315 .

8. Lizaka, S., Sugama, J., Nakagami, G., et al. Concurrent validation and reliability of digital image analysis of granulation tissue colour for clinical pressure ulcers. Wound Repair Regen 2011; 19: 4, 455-463.

9. Lizaka, S., Kaitani,T., Sugama, J., et al. Predictive validity of granulation tissue colour measured by digital image analysis for deep pressure ulcer healing: a multicenter prospective cohort study.Wound Repair
10. Sussman C, and Jensen BMB. Skin and Soft Tissue Anatomy and Wound Healing Physiology. In: Wound Care $4^{\text {th }}$ edition. Lippincott Williams \& Wilkins. Philadephia. 2012; 25.

11. Stremitzer S, Wild T, Hoelzenbein T. How precise is the evaluation of chronic wounds by health care professionals? Int Wound J 2007; 4: 156-61.

12. Lizaka S, Koyanagi H, Sasaki S, Sekine R, Konya C, Sugama J, Sanada H. Nutrition--related status and granulation tissue colour of pressure ulcers evaluated by digital image analysis in older patients. J Wound Care 2014;4: 198--206.

13. Sanada, H., Iizaka, S., Matsui,Y., et al. Clinical wound assessment using DESIGN--R total score can predict pressure ulcer healing: Pooled analysis from two multicenter cohort studies. Wound Repair Regen 2011; 19: 5.

14. Mukarramah DA, Sudjatmiko G. Perbandingan waktu penyiapan dasar luka antara penggunaan madu topical dengan convensional dressing pada luka trauma kronik. Jakarta. 2012.

15. Adifitrian T, Sudjatmiko G. Pengaruh Aplikasi Madu yang Ditutup Transparent Dressing Terhadap Waktu Epitelisasi pada Luka Donor Split Thickness Skin Graft. Jakarta. 2010.

16. Sundoro A, Sudjatmiko G. Perbedaan Madu Manuka dengan Madu Lokal dari Segi Sifat Kimia dan Fisika serta Fungsi Antibakterial. Jakarta. 2010.

17. Sudjatmiko G. Madu untuk Obat Luka Kronis. Yayasan Khasanah Kebajikan. Jakarta. 2011.

18. Greer SE, Mustoe T. Pressure Ulcers. In: Handbook of Plastic Surgery. Marcel Dekker. 2006. 